\title{
Penal Subversions: When is a punishment not a punishment, who decides, and on what grounds?
}

\author{
Lucia Zedner \\ University of Oxford, UK
}

\section{Introduction}

Punishment is a particularly problematic exercise of state power over the individual and, as such, it requires special justification. To talk of punishment without regard to what distinguishes it from other forms of coercion, risks undermining the possibility of justification and, no less importantly, critique (Ristroph, 2015). As states develop new coercive powers that evade the protections of the criminal process, criminology has responded by exploring the definitional borders of penality and their implications for criminological and penal theory (see eg Beckett and Herbert, 2010; Hannah-Moffat and Lynch, 2012: 119-121; Aas and Bosworth, 2013). Alert to possible expansions of state power, particular attention has been paid to the cloaking of sanctions as civil or administrative measures, whose punitive qualities are barely hidden (Robinson, 2001; Husak, 2011). States have been quick to claim that if a coercive measure or detention regime is for prevention or regulation or administrative convenience it is not, by definition, punishment. Yet this privileging of purpose does not mitigate the pains imposed by coercive measures, so to re-label measures as non-punitive is often nothing less than a cynical subversion of the criminal process and its human rights protections.

This article addresses three deceptively simple questions: when is a punishment not punishment? Who decides? And upon what grounds? It addresses them by analysing the significance for criminology of recent legal debates about the nature and scope of punishment. In so doing, it pursues the observation that much which 'is commonly described as criminological theory' is 'in large measure ... criminal justice theory, since its primary concern is with governmental and institutional responses to crime' (Ashworth, 2011: 343). The question of what constitutes a penal measure has been a matter of intense deliberation in Europe, in both national courts and at the European Court of Human Rights in Strasbourg. These courts have scrutinised measures formally labelled as non-penal where this designation seems to subvert the human rights protections applicable to the criminal process. Secondly, the question of who should decide reveals that punishment is not only a matter of academic debate, but also the subject of ongoing skirmish between governments and the courts in Europe. This conflict has resulted in a number of important cases that address how far governments have licence to brand measures as non-penal irrespective of the burdens they impose. In response, the courts have asserted their right to go behind formal labels to reach their own conclusions about whether measures are really punishments or not and, where they decide a measure is in fact penal, to apply the protections of the criminal process. This is not only a jurisprudential battle, it is also a profoundly political one about the nature of state authority and its power to punish. Finally, to ask 'on what grounds?' is to acknowledge that the definition of punishment is, at heart, a normative question. Defining what is and what is not punishment is not only indivisible from the question of justification, it is also inseparable from prior questions about what determines the boundaries of crime, who may punish, the protections owed to defendants, and the limits to sanctions consequently imposed. These debates go to the heart of what it means to talk about punishment and, as such have important implications for penal theory and for criminological 
theorising more generally (Hoyle and Bosworth, 2011). While the focus of this article is on recent disputes in Europe, the issues raised are no less germane to larger debates about punishment wherever they occur. ${ }^{1}$

\section{When is a punishment not a punishment?}

Punishment is a central term in the criminological lexicon, but it is far from safe to assume that we share the same criteria for identifying its meaning (Letsas, 2004: 279). Criminologists have long acknowledged that punishment is an essentially contested concept called upon to do descriptive, analytical, and normative work (Garland 1990; more recently see Simon and Sparks 2013). Disagreements about its meaning reflect differences of disciplinary background, are culturally informed by local language usage, by professional and institutional cultures (Garland, 2006), and the structures and practices of different penal systems (Cavadino and Dignan, 2006). Diverse intellectual approaches, whether broadly Durkheimian, Marxist, Weberian, Foucauldian (1979), or regulatory (Braithwaite, 2000) inform our respective conceptions of punishment, whether consciously or not. For those subject to punishment, these intellectual differences may matter less than whether the pains they suffer are fair, proportionate and legitimate.

\section{What lies at the core?}

Delineating the boundaries of punishment presupposes some consensus about what constitutes its core, where core is a synonym for 'least contested' or 'central case'. One pragmatic way of identifying what constitutes the core of any penal system is to identify the most severe penalty that 'anchors' the penal scale. Self-evidently, a jurisdiction that retains the death penalty sets its anchoring point significantly higher than one where life imprisonment is the most severe penalty and this has effects all the way down. It also has normative implications in that it allows us to ask 'What should be the scale's severest and most lenient penalties?'(von Hirsch, 1993: ch.5). In practice, this question is answered less often as a normative enquiry into the just level at which penalties should be set and, more commonly, as a comparative exercise in assessing and explaining the variations in severity within and between penal systems (Barker, 2009, ch.2; Lacey, 2008).

Recognising that severity of punishment differs markedly by jurisdiction helps to explain the European criminologist's surprise when American colleagues speak and write as if punishment and prison were synonymous (Whitman, 2005; Pratt and Eriksson, 2013. Beckett and Murakawa) are more honest than most when they acknowledge that they 'use the phrases "shadow carceral state" and "shadow penal state" interchangeably' (2012: 239). Their thesis is that, alongside the well-documented expansion of the US penal state, a shadow carceral state expands penal power through civil, administrative and hybrid legal forms and channels (Beckett and Murakawa, 2012: 222-223). Using 'the carceral state' as synonym for punishment may make sense in America, where imprisonment rates are very high. By contrast, in Europe, only a small fraction of sentences result in imprisonment and financial and non-custodial or community penalties dominate. ${ }^{2}$ This is not to deny the linguistic and culture dominance of the prison: even 'non-custodial' penalties are named for what they are not, by instinctive reference to custody. But there lies a hazard in allowing the prison to dominate linguistically and culturally. It gives rise to the 'anything but the prison' fallacy: namely, that any measure less than incarceration cannot be a subject of critique or complaint because something still nastier exists (von Hirsch, 1993). Until we displace the dominance of the prison in our theorising to recognise financial and non-custodial penalties as core cases of punishment, our ability to conceptualise penality or chart its boundaries is limited. 
Focusing on the severity and substance of penality is, of course, only a starting point for sociological and analytical endeavour. The real fights begin when we try to agree upon the normative preconditions and justifications for punishment. Is it uncontentious to say that punishment must be of an offender for an offence (Hart, 2008: 5)? That an offence must be set down in criminal laws that are sufficiently clear and certain to guide our conduct? If so, is punishment only that which is imposed following formal criminal proceedings, trial, and conviction? And to what principles and values ought these proceedings adhere? All these questions are inherently contentious and give rise to reasonable and possibly irresolvable dispute but they are too central to criminological theory to be left to the lawyers (Zedner, 2011).

The possible justifications for punishment enjoy still less consensus. Yet implicit in any morally defensible account is the unspoken adjectival constraint of 'justified' before 'punishment'. Although in ordinary language we may speak of burdensome or painful intrusions as 'punishing' - the 'punishing schedule' or 'punishing run' - such casual usage hinders identifying penal boundaries. Pain, coercion, repression, deprivation and exclusion are all common characteristics of punishment but they are not synonymous with it and nor are they justified as punishment. Using punishment as a crude synonym for pain or coercion fails to address whether and to what extent the burdens inflicted can be justified as punishment. And it obscures the stark fact that if a coercive measure is not justified as punishment then its burdens require independent justification. As Duff and Garland observe, 'Punishment requires justification because it is morally problematic. It is morally problematic because it involves doing things to people that (when not described as "punishment") seem morally wrong' (Duff and Garland, 1994: 2). This is not to presume that punishment can in fact be justified. Today, there are few penal abolitionists but they rightly place the onus upon us to defend an institution whose continued existence is otherwise assumed (de Haan, 1990; Mathiesen, 1974). In short, unless we sign up to absolute abolitionism, we cannot relieve ourselves of the obligation of trying to find a justification.

What then is it about punishment that needs justifying? Two fundamental elements of punishment, namely censure and sanction attract some consensus among some penal theorists (von Hirsch, 1993; von Hirsch, and Ashworth, 2005; Duff, 2007). So, a working definition of justified punishment might start with 'i) the censure of an offender for an offence, and ii) the intentional imposition of hard treatment on the offender for the offence' (Ashworth and Zedner, 2014a: 14). To prioritise censure is to recognise that punishment is first and foremost communicative. Censure is justified as a just societal response to an individual who has done wrong and by which society communicates disapproval proportionate to that wrong (Duff, 2001). Some argue that where a responsible individual is proven to have engaged in criminal conduct, censure is owed out of respect for their moral agency. ${ }^{3}$ On this view, not to punish a morally responsible offender would constitute a failure to acknowledge that individual as an autonomous agent. ${ }^{4}$ Placing censure centre stage has important implications for setting the boundaries of punishment because, presumptively, measures without this vital element do not satisfy as justified punishment and the attachment of sanction cannot follow. This way of thinking about punishment assumes as its subject the responsible, morally autonomous individual who can fairly be held to account for wrongdoing. Yet criminologists have rightly challenged this assumption by drawing attention to the radical conditions of inequality on grounds of economic deprivation and social class, in which many offenders act and its failure to advert to issues of age, gender, sexual orientation, and race (Hudson, 1998, 2006; Tonry, 2014). 
The second element, sanction, acknowledges that punishment goes beyond communication to inflict hard treatment upon the offender, which requires separate, more robust justification. Duff defines sanction as 'something intended to be burdensome or painful, imposed on a (supposed) offender for a (supposed) offence by someone who (supposedly) has authority to do so' (2001: xiv-xv). The repeated use of 'supposed' here is a sharp reminder of the fallibility of the criminal justice process. Sanction or 'hard treatment' is often defended as the only means by which censure can be communicated effectively (Tasioulas, 2006: 284). This claim may be persuasive in respect of criminal offences that are self-evidently wrongful, like homicide, rape, and assault. It is more problematic as an account of why we should punish the range of strict liability and regulatory offences which requires no mental element or direct harm, for which the need for sanction is less self-evident. Punishments that do not include hard treatment as part of their underlying rationale, like restorative justice (Cunneen \& Hoyle, 2010), seem to stand outside this definition of punishment (De Keijser, 2011). But, as criminological research has vividly shown, even measures justified as restorative, rehabilitative or therapeutic may be intrusive and burdensome (Nolan, 2001, ch.7).

Purely retributive accounts of punishment are rarely defended today (though see Moore, 1997); instead hybrid justifications that acknowledge retributivist, communicative and consequentialist elements prevail. For example, Ashworth and von Hirsch argue that criminal sanction is not only a means of censuring offenders, it is also a deterrent to us all in that it provides an additional 'prudential reason for desistance' from wrongdoing (2005: 22-23). ${ }^{5}$ This account acknowledges that we are all fallible and it curbs an otherwise dangerous tendency to conceive offenders as 'other' by allowing that punishment 'addresses ourselves, not a distinct “criminal” class' (von Hirsch, 2002: 409). To set sanction as supplementary and therefore subordinate to censure is insist that its deprivations be constrained by proportionality or 'fit' to the gravity of the offence. Note that no such restraint is to be found in purely consequentialist accounts of punishment, where the only limit is that the sanction is needed to achieve the desired goal (de Keijser, 2011), to which end even punishing the innocent might be justified.

Hybrid theories of punishment acknowledge that it embraces different purposes simultaneously, which has important implications for the setting of penal boundaries. Significantly, this means that the borders between penal and non-penal measures cannot be set by reference to purpose alone; so the claim that a measure is primarily preventive does not necessarily take it outside the realm of punishment. Such debates about what defines and justifies punishment largely remain the preserve of legal and penal theorists, which is a loss because greater engagement by criminologists in normative theorising would illuminate punishment's 'complexity of structure and density of meaning' (Garland, 1990: 282). Classic sociological accounts of punishment (from Weber to Foucault) reveal how far punishment is the exercise of state authority or governmental power but have less to say about how that power could or should be limited. Fusing the two together has significant potential to limit state power by identifying where punishment's boundaries ought to lie. To which question, we now turn.

What lies at the boundary?

If the core is uncertain, the boundaries of punishment are much more so. Particular difficulties arise in respect of coercive measure that are not formally designated as punishment but that are punitive in effect. Many exercises of quasi-punitive power are entrenched within the penal system: interrogation, police custody, and pre-trial detention, for example, have long been identified as quasi-penal methods by which impose discipline without the bother and cost of the trial. Feeley famously argued that for many offenders 'The Process is the Punishment' (1979, see also Choongh 1997). Other quasi-penal measures are of more recent origin. Across 
jurisdictions, the proliferation of summary proceedings, alternative sanctions, civil, administrative and regulatory measures, and forms of administrative detention play an increasing role in crime control (Ashworth and Zedner, 2010, 2014a ch.4; Ramsay, 2010; Dennis, 2012; Beckett and Murakawa, 2012; Bosworth, 2014). ${ }^{6}$ The use of civil measures against gangs, for example, is a widespread phenomenon is an important development, especially in the US and Australia (Smith, 2009, Alying, 2011, McGarrity, 2012). Similarly, the 'criminalization' of immigration control measures and use of administrative immigration detention signals a further expansion of state power (Sklanksy, 2012, McLeod, 2012, Bosworth 2014).

Such developments have been fed partly by frustration with the criminal process, backed by government claims that the 'paradigmatic sequence of prosecute on-trial-conviction-sentence' is slow, cumbersome, and 'ineffective' (Ashworth and Zedner, 2008, 2010). The strictures of neo-liberal economic rationality that now dominates political life has not spared the justice process (Garland, 2001), which is deemed too elaborate and expensive for minor offences. Swifter, cheaper measures like fixed penalties are commended as the more 'economic' alternative. The difficulty of getting witnesses to testify, problems of evidence and procedure contribute to high attrition rates, which further dents faith in criminal proceedings. The claim is that '[c]riminalising all regulatory offences leads to under-enforcement of certain types of offences' (Law Commission, 2010: 156). Concerns arise also about the capacity of criminal law to address persistent or repeat offending, anti-social behaviour, or ongoing conduct not easily encapsulated in a single criminal charge, like sexual or racial harassment, stalking, and domestic abuse. In the UK, prosecutors decline to resort to prosecution in cases of low level or non-harmful but risky conduct and, where they do, courts are said to impose penalties too low to deter or prevent. Whilte the unpredictability of the criminal trial fuels resort to alternative proceedings, particularly for less serious cases.

In response to such concerns, some continental European jurisdictions have adopted the strategy of moving lesser offences out of the criminal law to create a category of administrative or regulatory offences to target violations considered insufficiently serious to criminalise. In Germany the Ordnungswidrigkeitengesetz (Administrative Offences Act) 1968 re-designated a body of lesser crimes as administrative offences to reduce the caseload on the criminal courts, cut costs and distinguish lesser from more serious violations (Jost, 1997: 491; Spencer and du Bois-Pedain, 2005: 237). Resort to administrative offences allows regulatory authorities to impose penalties without recourse to formal court proceedings. The evidentiary requirements are lower, penalties are imposed pre-trial and are less onerous, consisting mostly of fines or prohibitions (Cabinet Office, 2006: 17: Paeffgen, 1991). Other benefits are said to be that administrative penalties are non-stigmatic, less disruptive of people's lives, and often better able to regulate minor misconduct. Like Germany, the UK has transferred some low level regulatory offences out of the penal process. In 2005, the Macrory Review concluded that that over-reliance on criminal prosecution as a means of regulatory enforcement had created a 'compliance gap' that left regulators unable to enforce non-compliance (2006). ${ }^{7}$ Reforms gave effect to a recommendation to introduce administrative penalties to regulators 'to impose proportionate, flexible and meaningful sanctions' to ensure future compliance (Ministry of Justice, 2009).

Of course, resort to extra-penal measures is hardly a European exclusive. For the US, Beckett and Murakawa argue that resort to civil procedures such as civil contempt and incarceration of debtors, civil commitment of sex offenders and incarceration of juvenile offenders for breach of a valid court order operate as 'shadow' forms of punishment that together 'significantly extend the reach and power of the penal state’ (2012: 232). Such developments can be observed 
across jurisdictions. Promoted by governments as legitimate endeavours to make good the failings of the criminal process, these 'shadow' forms are nonetheless covert extensions of state power that subvert due process protections.

\section{Procedural side-stepping}

We have seen that resort to administrative and regulatory offences is attractive to governments because it allows for cheaper, quicker, more 'effective' intervention than the criminal process. Emphasis on effectiveness is driven by a managerialist approach to public policy that prizes KPIs (Key Performance Indicators) over precepts of justice. Yet resort to administrative and civil channels involves procedural side-stepping that allows for the evasion of core criminal process protections, such as the presumption of innocence, the burden of proof on the prosecution, a standard of proof beyond reasonable doubt, rules of evidence, the right to legal defence, and a fair trial (Ashworth, 2006; Zedner, 2007). Even within the criminal process, erosions of these protections is common but at least they set standards to which existing penalties can be held, evasions measured and miscarriages identified. Civil and administrative channels impose fewer procedural hurdles, set lower evidentiary bars, and permit measures to operate unconstrained by the criminal process protections whose very purpose is to uphold the rights of defendants and guard against unwarranted state intrusion in individual liberty.

Note also that whereas justifications of punishment require that the offender can be held responsible for wrongdoing, non-penal measures do not rely for their justification on attribution of responsibility in the same way (Duff, 2010: 99). The pains and prohibitions imposed by formally non-penal measures may be burdensome or restrictive of liberty but they are not justifiable as punishment. Where measures seek to reduce or remove opportunities for particular conduct by restraining, banning, excluding, or confining persons subject to them, they fail to treat that individual as responsible. Instead, restraints are justified by reference to future risks, and operate on the assumption that, unless so restrained, the individual will go on to make wrong moral choices. For example, those subject to preventive orders can be prohibited from going to any place where it is thought that they might pose a risk (Ashworth and Zedner, 2014, ch. 4). Prohibitions can include bans on movement, association, and social activities, which have a damaging impact on the individual's ability to pursue ordinary employment, family and social life. Moreover, the length and duration of these orders is limited not by reference to the seriousness of an offence for which they have been convicted but is set by purely consequentialist considerations of prevention or regulation (Quirk et al, 2014).

In the UK, civil preventive orders are typically imposed for a minimum of two years. Given the wide variety of conduct to which these orders apply, these minimum terms create problems of proportionality that are exacerbated where breach results in imprisonment. ${ }^{8}$ So-called 'twostep devices' are imposed in civil proceedings on the 'balance of probabilities' standard of proof, but with a second step criminal sanction available for breach. ${ }^{9}$ This raises serious issues: what constitutes breach, to what standard of proof, and is there a risk of double punishments at the civil and criminal stage (von Hirsch and Simester, 2006)? Given that the initial conduct need not be criminal, the criminal sanction is imposed ostensibly for the breach itself. Yet the sentence is often set by reference to the conduct that gave rise to the initial order, which was neither necessarily criminal nor proven to a criminal standard of proof. ${ }^{10}$ Very similar problems arise in respect of civil orders imposed elsewhere, for example, the use of gang injunctions in the US (Maxson et al, 2005) and in Australia (Alying, 2011). 
All this is to say that governments should not be allowed to remove quasi-penal measures to less demanding procedural channels at whim. ${ }^{11}$ Claims made by governments that these orders are not penalties and so do not attract the protections of the criminal process or human rights are dubious. They have rightly become the object of much legal scrutiny in Europe. In a string of leading cases in the domestic courts and at the European Court of Human Rights in Strasbourg, the courts have directly addressed the question of what is and is not a punishment and asserted the right to police the boundaries of punishment. The issues addressed speak directly to the question of who wields penal power, on what grounds and how they might be restrained.

\section{Who decides and on what grounds?}

The role of the state

The machinery of punishment does not run itself: it is populated by human agents with diverse institutional, legal, and political affiliations and cultures. So there is much that could be said about the interplay among criminal justice officials, the public and even offenders in determining the nature and practices of punishment. The focus here, however, is on a different but no less important set of relationships, namely between governments and the courts as they tussle to assert their respective authority to determine what constitutes punishment. What follows is the history of a power struggle for the right to determine what punishment is and who should decide.

It is a truism of political theory that the power to punish is the prerogative of the state. It is one of the most important manifestations of state authority, which goes to the very heart of its relationship with citizens and non-citizens (Zedner, 2013). In classic political theory, the very raison d'être of the state is to provide conditions of security and order (Knowles, 2010). Only the state has the right to punish because only the state has the authority to set and police the boundaries of crime, to sanction those who transgress, and thereby to fulfil its security obligation (Thorburn, 2011: 88; Harel, 2008 Loader \& Walker, 2005). Accepting this account requires that we insert the word 'state' before punishment and that we regard as prima facie unjustified claims by non-state agents to have the power to punish. ${ }^{12}$

The question of who decides might seem, therefore, to invite a very short answer - the state; but this is too simplistic. To say that punishment is a state prerogative only raises further questions about the constitutional structures and political processes by which criminal law and punishment are instituted, reformed, and practised (Lacey, 2013). Although state penal power is formally limited by the separation of powers, with the legislature, executive and judiciary acting as checks and balances on each another, the reality is more complex. ${ }^{13}$ Public opinion, the media, pressure groups, victims' organisations and civil liberties organisations, have enormous influence on penal policy, and, in a market-driven society, so do financial and commercial interests (Wacquant, 2009). Parliamentary democracy renders the legislature responsive, sometimes too responsive, to public will. The pressures of the electoral cycle on penal reform and the influence of penal populism on reactive, often feverish law-making profoundly affect how punishment is configured and reconfigured (Pratt, 2007). As a consequence, even the supposedly 'settled' core of penality is 'volatile and contradictory' (O'Malley, 1999). The explosion of prison populations across many Western jurisdictions at a time of declining crime rates is just one example of the effects of political pressures upon elected representatives charged with making penal policy (Lacey, 2008: ch.1). To recognise the complex of political and social stresses, the impact of privatisation and of commercial 
interests on government makes clear that, in practice, punishment is a product of economic and power relations (Garland, 2001, Simon, 2007), some distance from the abstract entity envisaged by penal theorists.

\section{The role of the courts}

Although it is for the legislature to determine whether measures are designated criminal, civil or some hybrid of the two, this leaves open the question of whether the courts should simply accept the legislative designation ${ }^{14}$ or look behind labels to determine whether coercive civil measures are in fact penal. Governmental resort to legislative side-stepping of the criminal process to access the less onerous, faster and cheaper channels of civil and administrative law is arguably unjust where the measures imposed properly belong to the penal sphere. Where the courts simply defer to the legislature, they tacitly condone state subversion of criminal process protections and the strictures of proportionality that apply to punishment (Steiker, 1998). Judicial deference is a hazard because if courts uncritically accept legislative designation of a measure as not punishment the lesser procedural protections of civil or administrative procedure apply. In Europe, the courts have been unwilling to accede to this legislative undermining of due process protections. To the contrary, they have challenged formal designations, looked behind legislative labels, and insisted upon the right to apply independent criteria to determine whether or not a measure is punishment, irrespective of its official status. In so doing, they have challenged the notion that the defining punishment is a matter of legislative feat and instead insisted that terms like criminal charge and penalty are properly matters for the courts.

Crucially important has been the role of the European Court of Human Rights in Strasbourg in seeking to wrestle into existence an 'autonomous meaning' of punishment, independent of legislative labels applied by states that are signatory to the European Convention on Human Rights (ECHR). This innovative tactic, of insisting upon and elaborating an autonomous meaning of punishment, seeks to prevent states from classifying measures as non-penal so as to evade the strictures of the ECHR and deprive individuals of their fundamental rights (Emmerson et al, 2012: 100).

In order to set out criteria for determining the meaning of a 'criminal charge', three criteria were developed in the leading case of Engel. ${ }^{15}$ First, the formal label serves only as a starting point, behind which the court must look to determine the reality of the proceedings. Secondly, the court gives more weight to the nature of the offence and the proceedings to which it gives rise. ${ }^{16}$ Thirdly, the court pays particular attention to the severity of the penalty, particularly if the potential penalties (including those on breach of an order) entail imprisonment. If the order could result in a penalty that 'belongs to the criminal sphere' - and this can include even minor financial penalties - then this is enough for the court to hold the measure to be a criminal charge. The last two of these criteria - the nature of the offence and the severity of the penalty - are alternatives, that is either will suffice, but if each alone is not decisive they may be taken together to determine the outcome. These three 'Engel criteria' have been followed in important subsequent cases ${ }^{17}$ in order to prevent states from subverting the Convention by 'dressing up criminal proceedings as if they were civil' (Ashworth and Zedner, 2010: 77).

The Strasbourg Court's attempt to set out an autonomous meaning for the term 'penalty' is even more relevant to determining the boundaries of punishment (Emmerson et al, 2012: 846). The resulting 'anti-subversion doctrine' seeks to uphold the doctrine that there may be no punishment without law; to prevent states from sabotaging the prohibition on retrospective 
criminalisation; and to protect the provision that a penalty may not be increased retrospectively (Article 7 ECHR), as well as ensuring proportionality of sentence. In the leading case of Welch $v$ United Kingdom (1995), the Court held that 'To render the protection offered by Article 7 effective, the Court must remain free to go behind appearances and assess for itself whether a particular measure amounts in substance to a "penalty" within the meaning of this provision." 18 Welch concerned an order to confiscate the assets of a drug dealer that relied upon a law (the Drug Trafficking Offences Act 1986), which came into force after the date of Welch's conviction. Welch was successful in his argument that the order constituted a penalty and could not, therefore, be applied retrospectively.

In reaching its decision, the Court defined the autonomous meaning of a penalty by criteria analogous to those which apply to the term criminal charge. Again the starting point is whether or not the measure was imposed following conviction for a criminal offence but, again, this is not decisive. Other factors to be considered are 'the nature and purpose of the measure in question; its characterisation under national law; the procedures involved in making and implementation of the measure and its severity. ${ }^{19}$ Significantly these considerations were judged to override the government's claim that the purpose of the confiscation order was preventive not punitive, on the grounds that legislative purpose alone is not decisive. Note, however, that in the subsequent case of Ibbotson $v$ UK (1999), the question of whether a requirement that a sex offender register was a penalty was held to be purely preventive because the other factors were not sufficient and the requirements of the order were not so severe as to override its preventive purpose. ${ }^{20}$ So it is a complex and contested matter to decide where the boundary should lie.

Significantly, in the UK, in the leading case of Clingham and McCann (2003) the House of Lords ignored the reasoning in Welch that an order can be punitive in effect even if preventive in purpose. Instead, it found that because the restrictions imposed under an Anti-Social Behaviour Order (ASBO) were 'imposed for preventive reasons, not for punishment', it did not constitute a penalty. ${ }^{21}$ In so doing, the UK court strayed from the aim of the Strasbourg Court to prevent governments from manipulating categories on the civil-criminal/preventivepunitive border (Ashworth, 2004). The result was the rather unhappy conclusion that civil preventive orders sit somewhere on the margin, rules of civil evidence apply but the standard of proof is criminal. In consequence, UK civil preventive orders have been deemed neither penal nor preventive but some kind of mongrel crossbreed, a conclusion that could itself be considered a subversion of Strasbourg's 'anti-subversion' doctrine.

In cases where the deprivation of liberty in question is severe, however, such as preventive detention, the Strasbourg court has been much more robust in disallowing the claim that because the detention has a preventive purpose it is not punitive. In the case of $M v$ Germany, ${ }^{22}$ although the German Constitutional Court (the Bundesverfassungsgericht) had held that Sicherungsverfahren - a form of preventive detention - was 'of a purely preventive nature aimed at protecting the public from a dangerous offender', Strasbourg rejected this conclusion outright. It found that preventive detention was, in fact, a penalty on the basis that the detention of $\mathrm{M}$ took place in an ordinary prison in conditions similar to those of ordinary prisoners, there were no or few special measures to enable detainees to reduce the danger they presented and thereby limit the period of detention. It operated, therefore, as additional punishment and contained a clear deterrent element, it was ordered by the criminal courts, and the detriment to the offender was greater than the original sentence. Moreover, as an indeterminate order, it was among the most severe orders that could be made under the German Criminal Code. In short, mere declaration of a preventive purpose could not alter the fundamentally punitive quality of preventive detention. This judgment stands in striking contrast to the controversial decision of 
the US Supreme Court in Kansas $v$ Hendricks that because the purpose of post-sentence civil commitment was primarily to protect the public it was held to be civil, not punitive, detention. ${ }^{23}$

Subsequent judgments of the Strasbourg Court have insisted that if preventive detention is not to be deemed a penalty, conditions must be clearly distanced from those of imprisonment and that a therapeutic programme must be available. ${ }^{24}$ It is significant that subsequent decisions of the German Constitutional Court have expressly followed the Strasbourg case law in a move that has been applauded as signifying 'a new era of dialogue in European constitutionalism' (Michaelsen, 2012). No similar acquiescence can be seen in the case of McCann (discussed above) and many other UK cases in which the UK courts have explicitly ignored or rejected the Strasbourg determination of what is a penalty. To the contrary, the view of the UK seems increasingly to be that in setting itself up as arbiter of the boundaries of punishment, Strasbourg is meddling unwarrantedly in national affairs and undermining the sovereignty of the UK courts, even as they challenge the sovereignty of the UK parliament to determine what is and is not a punishment.

\section{Conclusion}

How should we think about this political and legal tussle to spring the meaning of punishment free from its official designation? Admirers of judicial activism have applauded the way in which judges have overcome their historic deference to government, particularly in matters of security, to uphold human rights by challenging instances of side-stepping or evasion (Emmerson et al, 2012). Critics have questioned whether, in a democracy, unelected and unaccountable judges should assume the right to challenge the will of parliament. The European Court on Human Rights has come under particularly hostile fire because its decisions on matters ordinarily considered to be the subject of national determination undermine parliamentary sovereignty (Letsas, 2004: 279-280). The European Convention on Human Rights is arguably part of the problem because its open textured provisions leave much scope for judicial discretion and the margin of appreciation permits widely differing interpretations. Its patchy and partial coverage is problematic too, not least because the Convention is largely silent on the protections that should apply to civil measures. As a result, the courts have been obliged to resort to the criminal sphere protections of Article 6 (right to a fair trial) and Article 7 (prohibition on retrospective penalties) to import procedural protections for individuals subject to coercive measures. By finding that a civil measure is, after all, a criminal charge resulting in a penalty, the courts can reimport the rule against retrospective punishment and the right to a fair trial. However heartily one might applaud this crafty reassertion of criminal process rights, key issues remain. What is the role of the courts in a democracy? Does the wielding of this interpretative power by the judiciary itself constitutes a problematic and undemocratic subversion of the government's power to designate what is and is not punishment?

Criminologists are not generally avid readers of case law but the cases discussed are enormously rich and provocative texts that raise profound questions about the authority of the state to set the boundaries of punishment. They invite further reflection about who has the power to punish and to determine what is (and is not) a penalty, indeed about the very limits of the sovereign state in its exercise of coercive power. Whether the determinative role the courts have accorded themselves is itself a subversion of state sovereignty demands criminological, as well as legal, attention since it directly addresses how penal power is exercised in contemporary society. In practice, the subversion, if it is one, may be more of a political issue 
than practical one in that court decisions are often undermined or sabotaged by states. The courts' self-appointed role in policing the boundaries of punishment may be commendable but whether it makes a decisive difference in practice remains less clear.

Punishment is the most powerful exercise of state authority over citizens so there are good reasons to designate coercive measures as punishment in order to reassert due process and human rights protections. But in their bid to bring coercive civil measures within the remit of human rights, the courts have arguably been insufficiently concerned with what justifies punishment as punishment. Seeking to secure protections for individual liberties by relabelling measures under the anti-subversion doctrine may be a case of the human rights tail wagging the definitional dog, because it subordinates the definition of punishment to the question of which procedural protections should apply. Upholding fundamental rights is laudable but it poses the question of what is and is not punishment the wrong way round. If criminologists might profit from examining further how the courts think about punishment, it is no less obvious that the courts could learn much from criminological and penal theory. 


\section{Corresponding author:}

Lucia Zedner, Faculty of Law, Centre for Criminology \& Corpus Christi College, University of Oxford, Oxford OX1 4JF, UK and Faculty of Law, UNSW, Sydney NSW 2052, Australia.

\section{Acknowledgements}

I am grateful to participants at the Penal Boundaries Workshop at the Centre for Criminology and Sociolegal Studies, University of Toronto (April 2014), seminar participants at the School of Social Policy, Sociology and Social Research, University of Kent (December 2014), and the anonymous reviewers for Theoretical Criminology for their helpful comments and suggestions.

This research received no specific grant from any funding agency in the public, commercial, or not-for-profit sectors.

\section{Contact Details}

Lucia Zedner

Corpus Christi College, University of Oxford, Oxford OX1 4JF, UK

Tel: 0186527624

Email: lucia.zedner@law.ox.ac.uk

\section{Author Biography}

Lucia Zedner is Professor of Criminal Justice in the Faculty of Law, a member of the Centre for Criminology \& Fellow of Corpus Christi College at the University of Oxford. She is also a Conjoint Professor in the Faculty of Law at the University of New South Wales.

\footnotetext{
${ }^{1}$ See eg, for the US (Beckett and Herbert 2010); for Canada (Hannah-Moffat K and Lynch M 2012), (HannahMoffat, K and Maurutto, P 2012); for Australia (Pickering SJ and Weber L 2006).

${ }^{2}$ For example, while the USA prison population is 748 per 100,000, the UK's prison population is 155 per 100,000 population, which is high compared to many European countries. In the UK (non-motoring) summary offences make up about $95 \%$ of all convictions, of which less than $3 \%$ were sentenced to immediate custody in 2013. The vast majority of summary offenders were sentenced to fines (74\%) or other non-custodial penalties. Even in respect of the most serious, 'indictable' offences, only $27 \%$ of offenders were sentenced to immediate custody.

${ }^{3}$ This sets to one side the question of what justifies criminalization and what conduct should be criminal (Duff, 2002; von Hirsch, 2002, Duff et al 2010).

${ }^{4}$ Censure is directed chiefly at the offender, its also acknowledges that the victim has suffered a harm wrongfully done and that the wrong offends against the public interest. Censure thus also speaks to the 'conscience collective' and sets out the formal limits of socially accepted behaviour (Lukes and Scull, 1983: ch.s 3 \& 4).

${ }^{5}$ The idea here being that ' $[\mathrm{t}$ ] he justification for inflicting hard treatment on offenders is preventive- - without hard treatment none of us would take a system of censure alone sufficiently seriously' Ashworth and Zedner, 2014b.

${ }^{6}$ In the UK, these include: summary measures (eg Fixed Penalty Notices, Penalty Notices for Disorder); civil preventive orders (eg Travel Restriction Orders, Football Spectator Banning Orders, Non-Molestation Orders, Risk of Sexual Harm Orders etc); hybrid preventive orders imposed in civil proceedings but backed up by criminal sanction, typically with a prison sentence for breach (eg Anti-Social Behaviour Orders, Sexual Offender Prevention Orders, Serious Crime Prevention Orders, Violent Offender Orders, Terrorism Prevention and Investigation Measures); and various forms of administrative or civil detention (eg civil commitment, preventive detention, immigration detention and so on).
} 


\footnotetext{
${ }^{7}$ The Macrory recommendations were accepted in full by the government resulting in a new system of civil sanctions made available to regulators under the Regulatory Enforcement and Sanctions (RES) Act 2008.

${ }^{8}$ Hybrid civil-criminal orders, such as the Anti-Social Behaviour Order (ASBO) were introduced to protect the public from 'behaviour that causes or is likely to cause harassment, alarm or distress' by prohibiting an individual from specific conduct or by limiting their mobility (Ashworth and Zedner 2014 ch.4).

${ }^{9}$ Breach of an ASBO attracted a sentence of up to five years' imprisonment. The ASBO has now been replaced by an Injunction that can be imposed on the very much more expansive ground that it is 'just and convenient to grant the injunction for the purpose of preventing the respondent from engaging in anti-social behavior.'

${ }^{10}$ (Duff, 2010: 100). Though see R (McCann) v. Crown Court at Manchester [2003] 1 AC 787, which held that a standard of proof equivalent to the criminal standard should be applied in respect of ASBOs

${ }^{11}$ On the grounds that '[p]lacing a measure in a particular legal context or procedural channel should not determine jurisprudential principle without reference to the normatively prior question of whether the choice of context is itself defensible' (Zedner, 2007: 265).

${ }^{12} \mathrm{Or}$ at least to allocate punishment, which leaves wide open the question of whether or not delivery of punishment may legitimately be delegated to private agents.

${ }^{13}$ Duff and colleagues make a similar observation about the constitutional structures of criminalization. See (Duff et al, 2011: 1-10. 8-9) .

${ }^{14}$ As is said to occur in some jurisdictions, eg Australia (Keyzer, 2011). See the leading Australian case of Fardon (2004) 210 ALE 50 and the condemnation of that decision in Fardon v Australia, UN Doc CCPR/C/98/D/1629/2007 (12 April 2010).

${ }^{15}$ In order to determine whether the right to a fair trial (Article 6 ECHR) applies. Engel v Netherlands (1979-80) 1 EHRR 647 at para 82.

${ }^{16}$ The symbiotic link between criminal law and punishment is much clearer in jurisdictions that conceive criminal law as penal law: the French speak of droit pénal, the Germans of Strafrecht, and the Italians of diritto penale - all of which make more obvious the internal constraints upon punishment that derive from criminalization.

${ }^{17}$ See for example, Ozturk v. Germany (1984) 6 EHRR 409; Benham v. United Kingdom (1996) 22 EHRR 293.

${ }^{18}$ Welch $v$ United Kingdom (1995) 20 EHRR 247, para 27.

${ }^{19}$ Welch $v$ United Kingdom (1995) 20 EHRR 247, paras 27-28.

${ }^{20}$ Ibbotson v United Kingdom (1999) 27 EHRR CD 332.

${ }^{21}$ Clingham v. Kensington and Chelsea LBC; R (McCann) v. Manchester Crown Court [2003] 1 AC 787.

${ }^{22}$ M v Germany [2009] ECHR No 1939/04.

${ }^{23}$ Kansas v Hendricks (1997) 117 S. Ct. 2072.

${ }^{24}$ Namely that preventive detention provisions must 'satisfy the constitutional requirement of establishing a distance between preventive detention and prison sentences'; be undertaken solely for preventive purposes; that no burdens beyond the deprivation of liberty are imposed; that detention must have 'a clear therapeutic orientation' designed to reduce the dangerousness of the offender and that therapy should be a legally enforceable right exercisable by the detainee; and that the detention must be subject to annual judicial review. Where preventive detention is imposed retrospectively it is a violation of both Articles 5 and 7. Mautes $v$ Germany (no. 20008/07) (13 January 2011); Kallweit v Germany (no 11792/07) (13 January 2011); Schummer v Germany (no 27360/04 and 42225/07) (13 January 2011).
}

\section{References}

Aas KF and Bosworth M (eds) (2013) The Borders of Punishment: Migration, Citizenship, and Social Exclusion. Oxford: Oxford University Press.

Ashworth A (2004) Social Control and Anti-Social Behaviour Order: the Subversion of Human Rights? Law Quarterly Review 120: 263-91.

Ashworth A (2006) Four Threats to the Presumption of Innocence. The International Journal of Evidence and Proof. 10: 241-279.

Ashworth A (2011) Criminal Justice, Not Criminology? In Hoyle C and Bosworth M (eds) What is Criminology? Oxford: Oxford University Press, 335-345. 
Ashworth A and Zedner L (2008) Defending the Criminal Law: Reflections on the Changing Character of Crime, Procedure, and Sanctions. Criminal Law and Philosophy 2: 2151.

Ashworth A and Zedner L (2010) Preventive Orders: a problem of under-criminalization? In: Duff RA et al (eds) The Boundaries of the Criminal Law. Oxford: Oxford University Press, 59-87.

Ashworth A and Zedner L (2014a) Preventive Justice, Oxford: Oxford University Press.

Ashworth A and Zedner L (2014b) Punishment Paradigms and the Role of the Preventive State. In: Simester A et al (eds) Liberal Criminal Theory: Essays for Andreas von Hirsch. Oxford: Hart Publishing, 3-21.

Alying J (2011) Pre-emptive Strike: How Australia is Tackling Outlaw Motorcycle Gangs. American Journal of Criminal Justice 36/3: 250-264

Barker V (2009) The Politics of Imprisonment: How the Democratic Process Shapes the Way America Punishes Offenders. New York: Oxford University Press.

Beckett K and Herbert S (2010) Penal Boundaries: Banishment and the Expansion of Punishment. Law and Social Inquiry 35: 1-38.

Beckett K and Murakawa N (2012) Mapping the shadow carceral state: Toward an institutionally capacious approach to punishment. Theoretical Criminology 16: 221244.

Bosworth M (2014) Inside Immigration Detention, Oxford: Oxford University Press.

Braithwaite J (2000) The New Regulatory State and the Transformation of Criminology. British Journal of Criminology 40/2: 222-238.

Cabinet Office (2006) Regulatory Justice: Sanctioning in a post-Hampton World, London: HMSO.

Cavadino M and Dignan J Penal Systems: A Comparative Approach, London: Sage.

Choongh S (1997) Policing as Social Discipline, Oxford: Clarendon Press.

Cunneen C and Hoyle C (2010) Debating Restorative Justice. Oxford: Hart Publishing. de Haan W (1990) The Politics of Redress: Crime, Punishment and Penal Abolition, London: Unwin Hyman.

De Keijser J (2011) Never Mind the Pain, It's a Measure! Justifying Measures as Part of the Dutch Bifurcated System of Sanctions' in Tonry M (ed) Retribution has a past. Has it a future? Oxford: Oxford University Press, 188-213.

Dennis I (2012) Security, Risk and Preventive Orders. In: Sullivan GR and Dennis I (eds) Seeking Security: Pre-empting the Commission of Criminal Harms Oxford: Hart Publishing, 169-192.

Duff RA (2001) Punishment, Communication and Community, Oxford: Oxford University Press.

Duff RA (2002) Punishment, communication and community. In: Matravers D and Pike J (eds) Debates in Contemporary Political Philosophy: An Anthology. London: Open University Press, 387-407.

Duff RA (2007) Answering for Crime: Responsibility and Liability in the Criminal Law, Oxford: Hart Publishing.

Duff RA (2010) Perversions and Subversions of Criminal Law. In: Duff RA et al (ed) The Boundaries of the Criminal Law. Oxford: Oxford University Press.

Duff RA et al (2010) (eds) The Boundaries of the Criminal Law. Oxford: Oxford University Press.

Duff RA et al (2011) Introduction. In: Duff RA et al (eds) The Structures of the Criminal Law. Oxford: Oxford University Press, 1-10. 
Duff RA and Garland D (eds) (1994) A Reader on Punishment. Oxford: Oxford University Press.

Emmerson B, Ashworth A and MacDonald A (2012) Human Rights and Criminal Justice, London: Sweet \& Maxwell.

Feeley M (1979) The Process is the Punishment: Handling Cases in a Lower Criminal Court, New York: Russell Sage Foundation.

Foucault M (1979) Discipline and Punish: the birth of the prison. Harmondsworth: Penguin.

Garland D (1990) Punishment and Modern Society: A Study in Social Theory. Oxford: Clarendon Press.

Garland D (2001) The Culture of Control. Oxford: Oxford University Press.

Garland D (2006) 'Concepts of Culture in the Sociology of Punishment', Theoretical Criminology, 10/4: 419-447

Hannah-Moffat K and Lynch M (2012) Theorizing Punishment's Boundaries. Theoretical Criminology 16: 119-121.

Hannah-Moffat, K and Maurutto, P (2012) Shifting and targeted forms of penal governance: Bail, punishment and specialized courts Theoretical Criminology May 16: 201-219.

Harel A (2008) Why only the state may inflict criminal sanctions: the case against privately inflicted sanctions. Legal Theory 14: 113-133.

Hart HLA (2008) Punishment and Responsibility Oxford: Oxford University Press.

Hoyle C and Bosworth M (2011) Mapping the Borders of Criminology. In Hoyle C and Bosworth M (eds) What is Criminology? Oxford: Oxford University Press, 530-542.

Hudson B (1998) Doing Justice to Difference in A. Ashworth and M. Wasik, (eds) Fundamentals of Sentencing Theory Oxford: Oxford University Press.

Hudson B (2006) Beyond white man's justice: Race, gender and justice in late modernity. Theoretical Criminology, 2/10: 29 - 47.

Husak D (2011) Lifting the Cloak: Preventive Detention as Punishment. San Diego Law Review 48: 1173-1204.

Jost P-J (1997) Regulatory Enforcement in the Presence of a Court System. International Review of Law and Economics 17: 491-508.

Keyzer, P (2011) The International Human Rights Parameters for the Preventive Detention of Serious Sexual Offedners. In McSherry B \& Keyzer P (eds) Dangerous People: Policy, Prediction and Practice. London: Routledge, 25-26.

Knowles D (2010) Political Obligation: a Critical Introduction, Abingdon: Routledge.

Lacey N (2008) The Prisoners' Dilemma: Political Economy and Punishment in Contemporary Democracies, Cambridge: Cambridge University Press.

Lacey N (2013) What Constitutes Criminal Law? In: Duff RA et al (eds) The Constitution of the Criminal Law. Oxford: Oxford University Press, 12-29.

Law Commission. (2010) Criminal Law in Regulatory Contexts: Law Commission Consultation Paper 195

Lazarus, L, Goold, B, and Goss, C (2013) Control without Punishment: Understanding Coercion. In: Simon, J and Sparks, R (eds) The SAGE Handbook of Punishment and Society. London: Sage, 463-491.

Letsas G (2004) The Truth in Autonomous Concepts: How to Interpret the ECHR. European Journal of International Law 15: 279-305.

Loader I and Walker N (2005) Necessary Virtues: The Legitimate Place of the State in the Production of Security. In J Wood and B Dupont (eds) Democracy, Society and the Governance of Security Cambridge: Cambridge University Press, 165-195.

Lukes S and Scull A (1983) Durkheim and the Law. Oxford: Martin Robertson. 
Macrory RB (2006) Regulatory Justice: Making Sanctions Effective Final Report, London: Cabinet Office.

Maxson C, Hennigan K and Sloane D (2005) “"It's Getting Crazy Out There”: Can a Civil Gang Injunction Change a Community?" Criminology and Public Policy. 4/3: 501-530.

McGarrity N (2012) 'From Terrorism to Bikies: Control Orders in Australia' Alternative Law Journal 37: 166-170

McLeod A M (2012) The US Criminal-Immigration Convergence and Its Possible Undoing. American Criminal Law Review, 49: 105-78

Michaelsen C (2012) "From Strasbourg with Love" - Preventive Detention before the German Federal Constitutional Court and the European Court of Human Rights. Human Rights Law Review 12(1): 148-167.

Mathiesen T (1974) The Politics of Abolition: Essays in Political Action Theory, London: Martin Robertson.

Ministry of Justice (2009) Guidance on creating new regulatory penalties and offences, London: MoJ.

Moore, MS (1997) Placing Blame, a General Theory of the Criminal Law. Oxford: Oxford University Press.

Nolan JL (2001) Reinventing Justice: The American Drug Court Movement. Princeton: Princeton University Press.

O'Malley P (1999) Volatile and Contradictory Punishment. Theoretical Criminology 3: 175196.

Paeffgen H-U (1991) Overlapping Tensions between Criminal and Administrative Law: The Experience of West German Environmental Law. Journal of Environmental Law 3: 247-264.

Pickering SJ and Weber L (2006) Borders, Mobility and Technologies of Control, Dordrecht: Springer.

Pratt J (2007) Penal Populism, London: Routledge.

Pratt J and Eriksson A (2013) Contrasts in Punishment: an explanation of Anglophone excess and Nordic exceptionalism. London: Routledge.

Quirk H, Seddon T and Smith G (2014) (eds) Regulation and Criminal Justice (Cambridge, Cambridge University Press.

Ramsay P (2010) Substantively uncivilized ASBOs. Criminal Law Review: 761-763.

Ristroph, A (2015) Just Violence. Arizona Law Review. 56(4) 1017-1063.

Robinson PH (2001) Punishing Dangerousness: Cloaking Preventive Detention as Criminal Justice. Harvard Law Review 114: 1429-1456.

Simester A P and von Hirsch A (2006) Regulating Offensive Conduct through Two-Step Prohibitions. In von Hirsch A and Simester AP (eds) Incivilities: Regulating Offensive Behaviour. Oxford: Hart Publishing, 173-94.

Simon, J (2007) Governing through Crime, Oxford: Oxford University Press.

Simon, J and Sparks, R (eds) (2013) The SAGE Handbook of Punishment and Society. London: Sage.

Sklansky D A (2012) Crime, Immigration, and Ad Hoc Instrumentalism. New Criminal Law Review, 15/2: 157-223.

Smith S (2000) Civil Banishment of Gang Members: Circumventing Criminal Due Process Requirements? University of Chicago Law Review 67/4: 1461-1487.

Spencer J and du Bois-Pedain A (2005) Approaches to Strict and Constructive Liability in Continental Criminal Law In: Simester A (ed) Appraising Strict Liability, 237-284.

Steiker C (1998) The Limits of the Preventive State. Journal of Criminal Law and Criminology 88: 771-808.

Tasioulas J (2006) Punishment and Repentance. Philosophy 81: 279-322. 
Thorburn M (2011) Constitutionalism and the Limits of the Criminal Law. In: Duff RA et al (eds) The Structures of the Criminal Law. Oxford: Oxford University Press, 85-105.

Tonry M (2014) 'Can Deserts be Just in an Unjust World?' in Simester, A et al (eds) Liberal Criminal Theory. Oxford: Oxford University Press, 141-165.

von Hirsch A (1993) Censure and Sanctions, Oxford: Oxford University Press.

von Hirsch A (2002) Punishment, penance and the state: a reply to Duff. In: Matravers D and Pike J (eds) Debates in Contemporary Political Philosophy: An Anthology. London: Open University Press, 408-422.

von Hirsch A and Ashworth A (2005) Proportionate Sentencing: Exploring the Principles, Oxford: Oxford University Press.

Wacquant L (2009) Punishing the Poor: the Neoliberal Government of Social Insecurity Durham \& London: Duke University Press.

Whitman JQ (2005) Harsh Justice: Criminal Punishment and the Widening Divide Between America and Europe. Oxford: Oxford University Press

Zedner L (2007) Seeking Security By Eroding Rights: The Side-Stepping of Due Process In: Goold B and Lazarus L (eds) Security and Human Rights. Oxford: Hart Publishing, 257-275.

Zedner L (2009) Security, London: Routledge.

Zedner L (2011) Putting Crime Back on the Criminological Agenda. In Hoyle C and Bosworth M (eds) What is Criminology? Oxford: Oxford University Press, 271-283.

Zedner L (2013) Is the Criminal Law Only for Citizens? A Problem at the Borders of Punishment. In: Aas KF and Bosworth M (eds) The Borders of Punishment: Migration, Citizenship, and Social Exclusion. Oxford: Oxford University Press, 40-57. 